\title{
Telaah Makna Gramatis dan Psikologis dalam Syair Abdul Muluk Karya Raja Ali Haji
}

\author{
Hadiwijaya $^{1}$; Sarwit Sarwono ${ }^{2}$; Didi Yulistio ${ }^{3}$ \\ Universitas Bengkulu ; Universitas Bengkulu²; Universitas Bengkulu ${ }^{3}$
}

Corresponding email: hadiwijaya.rawie73@gmail.com

\begin{abstract}
The purpose of this study was to describe the meanings obtained from the results of grammatical interpretation and psychological interpretation of the author towards Syair Abdul Muluk by Ali Haji using Schleiermacher's Hermeneutics. The research approach uses a qualitative approach with the hermeneutic method. The data collection technique uses documentation techniques in the form of Syair Abdul Muluk text by Ali Haji. The data analysis technique is done by reading poetry, identifying each event, interpreting the meaning, analyzing the relationships between the elements of poetry, and concluding meaning. Based on the from the research shows that the meaning contained in Syair Abdul Muluk by Ali Haji is that women can play a role like men in maintaining loyalty and achieving goals. Women can also be powerful even though they must condition themselves outside their nature as women. For Raja Ali Haji in the perspective of national culture and society, religion is a binding knot for various social levels in fostering culture.
\end{abstract}

Keywords: Poetry Study, Meanings, Grammatical Interpretation, Interpretation of Psychology, Hermeneutics

\begin{abstract}
Abstrak
Tujuan penelitian ini untuk mendeskripsikan makna-makna yang didapat dari hasil interpretasi gramatikal dan interpretasi psikologi penulis terhadap Syair Abdul Muluk karya Ali Haji menggunakan Hermeneutika Schleiermacher. Pendekatan penelitian menggunakan pendekatan kualitatif dengan metode hermeneutika. Teknik pengumpulan data menggunakan teknik dokumentasi berupa teks Syair Abdul Muluk karya Ali Haji. Teknik analisis data dilakukan dengan cara membaca syair, mengidentifikasi setiap peristiwa, menafsirkan makna, menganalisis relasi antar unsur syair, dan menyimpulkan makna. Berdasarkan hasil penelitian menunjukkan bahwa makna yang terkandung dalam Syair Abdul Muluk karya Ali Haji yaitu wanita dapat berperan layaknya laki-laki dalam mempertahankan kesetiaannya dan demi tercapainya tujuan. Wanita juga dapat berkuasa walaupun harus mengkondisikan dirinya di luar kodratnya sebagai wanita. Bagi Raja Ali Haji dalam perspektif kebudayaan bangsa dan masyarakat, agama merupakan simpul pengikat bagi berbagai macam tingkat sosial dalam pembinaan kebudayaan.
\end{abstract}

Kata Kunci: Telaah Syair, Makna, Interpretasi Gramatikal, Interpretasi Psikologi, dan Hermeneutika 


\section{PENDAHULUAN}

Syair Abdul Muluk karya Raja Ali Haji merupakan salah satu produk kebudayaan tradisional. Dalam teks aslinya Syair Abdul Muluk ditulis dalam bahasa Melayu Johor dan merupakan salah satu varian budaya Melayu yang cukup terkenal yang pertama kali dimuat dalam majalah Tidjchrift Van Netherlandsch Indie tahun 1847 (Fang, 1993:30). Syair sesunggguhnya merupakan bentuk puisi naratif Melayu tulis yang cukup lama diabaikan oleh dunia pengetahuan, namun sejak tahun 1960an, studi intensif tentang syair dilakukan (Braginsky, 1998:63). Dari hasil studi Braginsky tersebut, diketahui bahwa perkembangan tradisi syair seiring dengan masuknya agama islam ke Nusantara.

Dalam Khazanah kesusastraan Indonesia lama, setidaknya dijumpai sembilan puluh sembilan naskah yang termasuk kelompok syair dan puisi yang terbagi dalam empat puluh empat judul (Sutaarga, 1972: 74). Berdasarkan isi, tema dan tokohnya, syair terbagi ke dalam lima kelompok yaitu: (1) syair romantis, (2) syair sejarah, (3) syair alegoris, (4) syair keagamaan, dan (5) syair didaktis (Braginsky, 1998: 236).

Berdasarkan klasifikasi di atas, Syair Abdul Muluk merupakan produk karya sastra Melayu Tradisional berbentuk puisi yang tergolong pada syair romantis. Syair ini juga dapat disebut sebagai cerita berbingkai karena mengisahkan satu tema mayor yaitu kesetiaan seorang istri kepada suaminya yang dalam pengisahannya syair ini disusun dari delapan belas bagian, terbagi dalam empat episode, dan tiaptiap bagian mempunyai sub tema yang berbeda namun mempunyai keterkaitan dalam hubungannya untuk mendukung tema mayornya. Bahasa yang digunakan dalam teks syair ini adalah bahasa Melayu yang ditulis dalam aksara Arab Melayu, ejaan dan bahasa yang digunakan dalam syair ini dalam beberapa bentuk menunjukkan ciri bentuk bahasa lama yang tidak lazim lagi digunakan saat ini, hal ini dapat terlihat dari pilihan kata, pembentukan kata dan pembentukan kalimat-kalimat dalam bait syair.

Syair Abdul Muluk diasumsikan banyak sekali terkandung nilai-nilai kehidupan yang positif baik yang tersurat secara eksplisit dalam bagian-bagian bait syairnya, maupun yang tersirat melalui makna-makna kias yang terkandung dalam bagianbagian bait syair yang tersusun. Makna dari nilai-nilai tersebut merupakan pesan yang akan disampaikan Sutan Ali Haji kepada pembaca atau pendengar syair Abdul Muluk yang berkenaan dengan bagaimana umat manusia secara universal harus bertindak, bertingkah laku pada dirinya sendiri maupun dalam interaksinya pada sosial masyarakat dan kepada Sang Pencipta. Hal ini penting bagi Raja Ali Haji dimana Raja Ali Haji dalam perspektif kebudayaan bangsa dan masyarakat, agama merupakan simpul pengikat bagi berbagai macam kelompok sosial dalam pembinaan kebudayaan. Bertindak dan bertingkah laku dalam berinteraksi dan bersosialisasi pada masyarakat.

Syair Abdul Muluk jika dikaitkan dengan pembelajaran Bahasa dan Sastra Indonesia maka syair ini dapat menjadi salah satu alternatif bahan pembelajaran untuk meningkatkan apresiasi sastra klasik siswa, untuk menambah wawasan dalam memahami nilai-nilai yang bersifat edukatif, sarat dengan pesan-pesan budaya dan filsafat hidup. Selain itu syair juga harus mengemukakan ciri-ciri formal syair berupa: a) satu bait terdiri dari empat baris (larik); b) tiap larik terdiri dari dua bagian yang sama; c) pola sajak (rima) akhir syair berupa sajak sama: a-a-a-a; d) keempat baris syair saling berhubungan membentuk cerita; e) dalam syair satu bait, belum selesai; dan f) syair bersifat epis, yaitu berupa cerita (Pradopo, 1998: 26). 
Berdasarkan hal tersebut maka dalam penelitian ini mencoba menafsirkan makna-makna positif dalam Syair Abdul Muluk yang didapat dari hasil interpretasi gramatis terhadap makna yang menyangkut hubungan intra bahasa, atau makna yang muncul sebagai akibat berfungsinya sebuah kata dalam kalimat (Djajasudarma, 2013:54) dan interpretasi psikologis terhadap kepengarangannya (meliputi: individu, keluarga, generasi, masyarakat, kultur, negara, dan zaman). Ada tiga hal sehubungan dengan usaha menjelaskan istilah makna yaitu, (1) menjelaskan makna kata secara ilmiah, (2) mendeskripsikan kalimat secara ilmiah, dan (3) menjelaskan makna dalam proses komunikasi (Kempson, 1977:11 dalam Pateda, 2010:79).

Penelitian terhadap Syair Abdul Muluk sudah pernah dilakukan oleh penelitipeneliti sebelumnya yaitu tentang dalam buku Inilah Syair Abdul Muluk: Tentang Struktur dan Teks Karya Raja Ali Haji (Arfani, 2016). Dalam buku ini Arfani mengulas tentang bagian-bagian teks dengan pendekatan struktur teks Syair Abdul Muluk yang kemudian dikaitkan dengan seni pertunjukan teater tradisional Abdul Muluk yang berkembang dan masih dilestarikan di daerah Kota Palembang, Provinsi Sumatera Selatan. Syair Abdul Muluk juga pernah dikaji oleh Zaini-Lajoubert (1994:23) dengan mengkaji presentasi makna syair yang dihadirkan sebagai cerminan budaya budaya kehidupan raja yang santun dan bijak terhadap setiap orang.

Penelitian berikutnya, pernah dilakukan oleh Rudianto (2013) tentang analisis nilai-nilai budi pekerti dalam Syair Abdul Muluk karya Raja Ali Haji. Penelitian ini berupa skripsi di lembaga pendidikan Jurusan Pendidikan Bahasa dan Sastra Indonesia, Fakultas Keguruan dan IImu Pendidikan Universitas Maritim Raja Ali Haji, Tanjung Pinang. Dalam tulisannya Rudianto meneliti nilai-nilai perilaku positif yang dapat dimanfaatkan sebagai pembelajaran pendidikan karakter siswa bahkan masyarakat secara luas.

Meskipun penelitian sudah pernah dilakukan terhadap Syair Abdul Muluk namun penelitian ini berbeda dengan penelitian-penelitian yang sudah dilakukan sebelumnya, karena penelitian ini disandarkan pada teori Hermeneutik Schleiermacher yang memberikan ruang bagi peneliti, pembaca, atau pengguna karya sastra untuk mengapresiasi dan menafsirkan makna karya sastra yang dibacanya. Pada akhirnya nanti bisa dimanfaatkan dan dapat pula dikaji oleh peneliti lain dalam kemungkinannya untuk dijadikan sebagai media tranformasi pendidikan karakter masyarakat khususnya anak-anak usia sekolah melalui karya sastra klasik Syair Abdul Muluk.

\section{METODE}

Pendekatan penelitian menggunakan pendekatan kualitatif dengan metode hermeneutika. Ratna (2013: 230) menjelaskan bahwa kata hermeneutika berasal dari bahasa Yunani yaitu kata herme yang berarti mengatakan sesuatu. Dalam bentuk kata benda (hermeneia) bisa berarti interpretasi, sedangkan dalam bentuk kata lainnya hermeneus berarti orang yang menafsirkan. Dalam mitologi Yunani Hermeneutika merupakan seni interpretasi yang digunakan untuk memperoleh makna yang lebih luas dari pesan-pesan religi yang dilakukan oleh Hermes sebagai dewa pembawa pesan Illahiah sesuai dengan konteks kepercayaan Yunani pada masa itu. Dalam proses interpretasi yang dilakukan ada tiga ciri, yaitu a) mengungkapkan kata-kata secara lisan, b) menjelaskan suatu- situasi sehingga masuk akal, dan c) menerjemahkan dari satu bahasa ke bahasa lain.

Teknik pengumpulan data menggunakan teknik dokumentasi berupa teks Syair Abdul Muluk karya Ali Haji. Data penelitian ini berupa interpretasi gramatikal 
dan interpretasi psikologis yang terdapat pada teks naskah Syair Abdul Muluk yang dapat dipahami melalui terjemahan berdasarakan analisis Hermeneutika Schleiermacher.

Syair Abdul Muluk secara keseluruhan terdiri dari delapan belas bagian. Dengan demikian data yang digunakan dalam penelitian ini pun diusahakan merepresentasikan kedelapan belas bagian teks tersebut. Data dalam penelitian ini adalah berupa kata, baris, bait, atau bagian-bagian dalam teks ini yang merupakan unsur-unsur yang menjalin relasi atau hubungan sehingga membentuk makna tertentu. Data tersebut diidentifikasi melalui peristiwa atau jalan cerita, penokohan, dialog antar tokoh, kata atau frasa dan kalimat, atau hal-hal lainnya yang merupakan penanda yang dapat dijadikan bahan kajian dalam penelitian ini untuk menafsirkan makna-makna dalam Syair Abdul Muluk.

Teknik analisis data dilakukan dengan cara: 1. Membaca dan memahami setiap bagian dan keseluruhan teks tejemahan Syair Abdul Muluk karya Raja Ali Haji yang bersumber dari Perpustakaan Nasional Republik Indonesia dengan nomor registrasi Provisional Reel List No. 109, MS call no.W257 PNRI. 2) Mengidentifikasi peristiwa atau jalan cerita baik bagian-perbagian maupun secara keseluruhan dari teks tejemahan Syair Abdul Muluk karya Raja Ali Haji, mendata kata, frasa, atau kalimat-kalimat yang merupakan ikon, simbol, atau penanda dalam teks. 3) Mengapresiasi, menginterpretasi, dan menafsirkan makna kata, frasa, atau kalimatkalimat, baris, bait, atau bagian-bagian dari teks tejemahan Syair Abdul Muluk karya Raja Ali Haji. 4) Menganalisis relasi antara kata, frasa, atau kalimat-kalimat, baris, bait, atau bagian-bagian dari teks tejemahan Syair Abdul Muluk karya Raja Ali Haji. 5) Membuat simpulan hasil penelitian atau kajian makna keseluruhan dari teks tejemahan Syair Abdul Muluk karya Raja Ali Haji.

\section{HASIL}

1. Hasil Analisis Gramatis Syair Abdul Muluk Karya Ali Haji

Kajian Syair Abdul Muluk karya Raja Ali Haji banyak ditemukan berbagai bentuk tanda. Tanda terdiri dari simbol ( tanda yang muncul dari kesepakatan), icon ( tanda yang muncul dari perwakilan fisik), dan indeks (tanda yang muncul dari hubungan sebab akibat). Dalam Syair Abdul Muluk ini banyak terdapat makna tanda yang berupa icon, indeks, dan simbol. Tanda-tanda tersebut tersebar dalam tiap-tiap bagian dan episode yang ada pada Syair. Berdasarkan hasil penelitian, tanda banyak ditemukan dalam syair ini, maka kebahasaan yang merupakan makna tersirat dapat diketahui melalui tuturan yang dilontarkan antar tokoh.

Pemaknaan Syair Abdul Muluk diangkat dari tuturan-tuturan yang terdapat pada teks Syair Abdul Muluk yang mengungkapkan pikiran-pikiran penulis untuk menemukan pemahaman terhadap teks. Dalam sistem kerja Hermeneutika dilihat sebagai hubungan dengan sumber acuan, muncul dari hubungan sebab-akibat, dalam Syair Abdul Muluk ini sebagai penanda dapat dilihat pada latar cerita yang diceritakan dalam syair ini.

Icon, simbol, dan indeks pada Syair Abdul Muluk ini muncul dalam kebahasaan yang bersifat pararel, hal ini dapat dilihat pada setting cerita syair ini pada epidose pertama yang merupakan orientasi adalah isi dari Syair Abdul Muluk pada bait 1 sampai bait 491 yang bercerita tentang empat kerajaan besar pada masalahmasalah manusia yang ada di dalamnya. Sebagai pembuka diceritakan negeri Barbari sebagai negeri yang aman dan makmur, yang diperintah oleh Sultan yang masyur dengan sangat menjunjung tinggi aturan yang telah ditetapkan, terutama 
dalam perdagangan. Kemudian negeri Ban juga disebut sebagai negeri yang damai diperintah oleh Sultan nan bijaksana, yang pada suatu ketika mengalami pertanda alam berupa hujan tujuh hari tujuh malam, menjelang kelahiran Sitti Rafiah. Kerajaaan ini mempunyai benteng pertahanan yang kuat karena banyak meriam dipasang di seputaran balairung istana.

Kemudian negeri Hindi yang digambarkan sebagai negeri yang besar juga mempunyai armada pasukan yang kuat dan dipimpin oleh raja yang pemarah, dan terkhir adalah negeri Barham yang baru saja mengalami pergantian Sultan, yaitu Sultan Jamaluddin karena Sultan sebelumnya mangkat. Negeri ini digambarkan negeri yang suram karena terjadi pemberontakan Bahsan, pamanda Jamaluddin yang menginginkan kekuasaan yang akhirnya Bahsan dibunuh oleh Sitti Rafiah dengan nama Samaran Duri. Sistem kenyataan faktual dimainkan oleh manusiamanusia atau tokoh-tokoh syair Abdul Muluk pada peran mereka dalam pemaknaan teks. Seperti dalam kutipaan teks Syair Abdul Muluk bagian 1 bait 22 di bawah ini:
Abdul Muluk putra nin tuan
Besar lah sudah emas tempawan
Elok majelis tiada berlawan
Suka bermain cara pahlawan

Dalam kutipan syair di atas Abdul Muluk berkedudukan sebagai Icon, yaitu pemakna yang muncul dari perwakilan fisik manusia, yang merupakan putra bangsawan dari negeri Barbari anak dari Sultan Abdul Hamid Syah, yang berfungsi sebagai penghubung sebab-akibat. Dimana Abdul Muluk merupakan penerus generasi kerajaan, simbol penerus kerajaan ini terlihat pada kalimat 'besarlah sudah emas tempawan', yang terdapat pada teks syair bagian I bait ke 22 , dimana diartikan sebagai Abdul Muluk adalah Putra Mahkota kerajaan Barbari.

Kemudian, pada kaitan penceritaan berikutnya diceritakan Sultan Syahbuddin raja negeri Hindi, merasa resah mendengar kabar atas kematian pamannya Bahauddin karena tidak mau makan di penjara negeri Barbari. Keresahan Sultan Hindi ini digambarkan dalam kutipan syair bagian II bait 45-45 yang merupakan episode kedua yaitu komplikasi dan evaluasi, merupakan isi syair bait ke 492 sampai bait 1302.

\author{
Adapun akan sekalian hambanya \\ Kembalilah la ke negerinya \\ Mempersembahkan kabar kepada tuannya \\ Baginda pun terkejut sangat masygulnya \\ Mendengar kabar paduka \\ Sambil terpekur duli paduka \\ Sepatah pun tiada Sultan bersabda \\ Anguslah hatinya di dalam dada
}

Dalam penafsiran syair di atas Sultan Hindi saat mendengar berita kematian pamannya langsung terdiam tidak berkata apa pun sampai sedih dan berduka yang teramat dalam. Pada kutipan yang menjadi bentuk 'mendengarkan kabar paduka ayahanda' yang kemudian berhubungan kepada reaksi Sultan yang terdiam 'terpekut duli paduka, sepatah pun tiada Sultan bersabda' yang kemudian dilanjutkan pada lirik terakhir '( $h$ ) anguslah hatinya di dalam dada' yang ditafsirkan sebagai Sang Sultan sangat gundah dan bersedih. 
Pertalian pada cerita berikutnya adalah ketika Sultan Abdul Muluk berlayar dan merapat ke sebuah negeri bernama Ban yang dikabarkan mempunyai seorang anak perempuan cantik jelita. Kepada Sultan Ban, Sultan Abdul Muluk melamar Sitti Rafiah melalui utusan seorang Wazir atau Perdana menteri, melalui kutipan syair bagian kelima bait 30-31:

Sembah takzim anakanda Sultan

Ke bawah dulu yang dipertuan

Harapakan ampun yang kelimpahan

Harapan tuanku belas dan kasihan

Harapan anakanda tiada berperi

Kepada tuan ku laki istri

Jika ada ampun segera di beri

Memohon mestika di dalam negeri

Dengan bahasa yang cukup indah dan mempesona Wazir perdana menteri menyampaikan niat Sultan Abdul Muluk Untuk melamar Siti Rafiah, sehingga Sultan Ban pun luluh dibuat. Acuan terjemahan 'sembah tahzim anakanda Sultan ke bawah duli yang dipertuan' merupakan penggambaran awal syair sebagai bentuk perhormatan kepada Sultan Ban sebagai muasal niat Sultan Abdul Muluk yang diteruskan dengan kalimat ' harapkan ampun yang kelimpahan, harapakan tuanku belas dan kasihan, harapnya anakanda tiada berperi, kepada tuanku laki bini' sebagai perwakilan dari fisik manusia (indek) yang mengindikasikan keberadaan posisi Abdul Muluk yang berniat melamar Sitti Rafiah. Kalimat pada syair ini bukanlah kalimat merendahkan diri, tetapi sebagai bentuk untuk menghubungkan situasi dan keadaan pemohon dan termohon yang kemudian dilambangkan dengan kalimat 'jika ada ampun segera diberi, memohon mestika di dalam negeri'.

Hubungan pemohon sebagai bentuk, dan memohonkan sebagai konsep permintaaan kepada Sultan yang dilambangkan mestika di dalam negeri yang diartikan meminta perhiasan negeri atau sebagai lamaran akan anak perempuan satu-satunya.

Kelang beberapa lamanya setelah pulang ke negeri Barbari, Sultan Abdul Muluk bersama Sitti Rafiah yang telah dipersuntingnya, terjadilah huru-hara di negeri Barbari atas serangan pasukan Raja Hindi yang membalas dendam atas kematian Bahauddin pamannya raja Hindi, la ditangkap dan dipenjara bersama Sitti Rahmah dan Wazir Suka, dan Sitti Rafiah berhasil melarikan diri dari sergapan tentara Hindi. Pada bagian ini maka dimulailah petualangan Sitti Rafiah yang penuh derita dan tantangan. dalam pelariannya di hutan Sitti Rafiah mengalami tantangan yang begitu dahsyat, sampai la pun harus menghadapi harimau buas seperti dalam kutipan syair bagian sembilan bait 40-43:

la memandang serta dilihatnya

Binatang yang lari ada mengejar

Seekor binatang hebat rupanya

Seperti darah warna merahya

Rafiah pun sangat rasa ngeri

Menghunus pedangnya bangkit berdiri

Binatang menerkam datang berlari

Diturunkan pedang oleh putri

Setelah mati sudahlah binatang 
Kepada misainya la terpandang

Hanya lah sehelai terlalu panjang

Panjangnya konon sebelit pinggang

Misai binatang sudah diambilnya

Lalu diikatkana kepada pinggangnya

Hilanglah segala letih lesunya

Jadilah kuat perasaannya

Pada kutipan di atas ujian yang sangat berat dialami Sitti Rafiah, dalam hamil tiga bulan ditengah hutan saat la melihat sekerumunan binatang-binatang berlarian dikejar oleh seekor hewan buas, dan mau tidak mau Sitti Rafiah harus menghadapinya dengan bermodalkan sebilah pedang sampai la berhasil membunuh hewan buas tersebut. Pendeskripsian perwakilan bentuk fisik pada kutipan ' la memandang serta dilihatnya, binatang yang berlari, ada menghunus pedangnya bangkit berdiri, ditahankan pedangnyan oleh puteri'. Pada dua kutipan ini sebagai langkah pertama menggambarkan bagaimana situasi Sitti Rafiah ketika melihat dan harus menghadapi binatang buas tersebut.

Kemudian pada kutiapan syair ' binatang datang menerkam datang berlari, dihunuskan pedang oleh puteri'. Menerangkan tentang Sitti Rafiah benar-benar harus menghadapi binatang buas tersebut. Dalam kutipan binatang menerkam datang berlari, ditahan pedangnya oleh puteri....setelah mati sudahlah binatang '. Mengisyaratkan bahwa Sitti Rafiah berhasil membunuh binatang buas itu. Menjadi pertanyaan adalah tentang jenis binatang buas yang disimbolkan Raja Ali Haji dalam Syair Abdul Muluk ini. Dilihat dari kutipan 'seekor binatang hebat rupanya, seperti darah warna bulunya....kepada misainya la terpandang '. Dengan menilik dari kata menerkam, misai (kumis) maka yang mendekati ciri binatang yang disebutkan adalah harimau. Walau agak sedikit berlebihan pengarang menuliskan kehebatan hewan tersebut dengan 'seekor binatang hebat rupanya, seperti darah warna bulunya, kepada misainya la terpandang, hanyalah sehelai terlalu panjang', panjangnya konon sebelit pinggang, dan kutipan hewan ini berukuran sangat besar, sampai sehelai misai ( kumis) dapat diikatkan ke pinggang Sitti Rafiah.

Setelah Sitti Rafiah selamat dari hewan buas tersebut, maka la melanjutkan pengembaraannya. Pada keadaan letih dan akhrnya la menemukan rumah seorang Syeh Ulama tersebut dan dipelihara oleh keluarganya sampai suatu masa la melahirkan Abdul Gani dan merasa sudah tiba waktunya untuk kembali mengembara menuju negeri Hindi. Sitti Rafiah pun dibekali dan diajarkan beberapa ilmu bela diri dan strategi oleh Syeh Ulama. Dalam segala usaha akhirnya Sitti Rafiah berhasil menaklukan negeri Hindi bersama negeri Barhan dan menjadi Sultan, serta menyelamatkan Sultan Abdul Muluk, Sitti Rahmah, dan Wazir Suka. Sampai akhirnya Sitti Rafiah yang menyamar sebagai Sultan Duri menunjukkan identitas dirinya dihadapan Sultan Abdul Muluk, seperti kutipan syair bagian 17-20:

Duri pun masuk pula ke dalam

menanggalkan bajunya buatan Barhan

tinggal yang tipis baju di dalam

ke tengah istana berjalan Syah Alam

Setelah dilihat Sultan Barbari

Nyatalah rupanya Rafiah Puteri

Berpandang-pandangan laku istri

Hendak di tegur rasanya ngeri 
Sultan berpikir seorang-orang

Tidak ditegur Sultan dermawan

la pun masuk ke dalam peraduan

Lalu memakai seperti perempuan

Keluar pula Sitti Bastari

Sujud dikaki Sultan Barbari

Dengan tangisnya Sitti Arabi

Baginda terkejut dilihatnya istri

Kutipan syair di atas adalah titik balik dalam cerita Syair Abdul Muluk yang merupakan epidose ketiga yaitu resolusi. Dimana masalah sudah mendapat penyelesaian yang merupakan isi dari bait ke 1303 sampai bait 1695. Dimana Sitti Rafiah membuka identitasnya yang selama ini menyamar sebagai seorang laki-laki bernama Duri. Pada kutipan 'Duri pun masuk ke dalam, menanggalkan bajunya buatan Barhan, tinggal yang tipis baju di dalam'. Sebagai pengetian penampakan diri Sitti Rafiah kepada Sultan Abdul Muluk, sebagai kunci dari semua rentetan cerita. kemudian pada kutipan ' keluar pula Sitti Bastari, sujud di kaki Sultan Barbari, dengan tangisnya Sitti Arabi'. Dapat diartikan sebagai bentuk penghormatan Sitti Rafiah yang masih menganggap dan mencintai Sultan Abdul Muluk sebagai suaminya, dan sebagai kisah balik. Hal ini sesuai dengan ramalan ahli nujum kepada Sultan Ban saat Sitti Rafiah menjelang kelahirannya, bahwa la akan menghadapi berbagai cobaan dan sangat taat pada suaminya.

Kutipan selanjutnya 'setelah dilihat Sultan Barbari, nyatalah rupanya Rafiah Putri. Seakan ingin digambarkan oleh penyair mereka benar-benar telah melepaskan segala penderitaan dan duka akan lama tidak bertemu, Sitti Rafiah sebagai tokoh yang dominan dalam cerita syair ini, sebagai sumber acuan penceritaan. Mengalami banyak penderitaan sampai membalaskan dendam dan menyelamatkan suaminya, disimbolkan dalam ucapan ahli nujum tentang 'anakanda nin sangat besar tuahnya, sangat berkhidmad kepada suaminya mendapatkan suami dari pada kesaktian'.

\section{Hasil Interpretasi Psikologis dalam Syair Abdul Muluk Karya Ali Haji}

Interpretasi psikologis berfokus pada apa itu subjektif dan individual. Berdasarkan pendekatan Hermeneutika Schleirmacher penafsiran makna teks secara psikologis diawali dengan menganalisis individu penulis, keluarga, generasi, masyarakat, kultur, negara dan zaman.

a. Hasil Interpretasi Psikologis dalam Individu Penulis

Teks ditempatkan dalam konteks sosial, dengan demikian konsep tindakan pemahaman makna sebagai teks mengizinkan teks memberikan kepercayaan kepada diri manusia dengan cara yang objektif. Memahami teks berarti memahami individu, setiap individu memiliki perberdaan dalam bahasa tulis dan bahasa lisannya. Memahami kepribadian penulis, pikiran-pikiran penulis melalui bahasa dan tuturan yang dipakainya melalui teks, antara tuturan bahasa dan kepribadian penulis secara individual memiliki kedudukan setara dengan interpretasi gramatis dengan interpretasi psikologis, keduanya saling berhubungan dan saling mengandalkan.

Syair Abdul Muluk interpretasi individualnya dapat dilihat dari tuturan bahasa yang digunakan Raja Ali Haji. Melalui tuturan yang disampiakan oleh Raja Ali Haji dalam syair terdapat kehalusan budi seorang Raja Ali Haji. Kehalusan budi seorang Raja Ali Haji tercermin dari bait-bait syair yang disampikannya selalu menyampaikan 
pujian-pujian dan menjaga setiap tutur katanya agar orang lain tidak tersinggung dengan tuturannya. Hal ini dapat dilihat dari kutipan Syair Abdul Muluk bagian I bait ke 21:

Pandailahaa sudah berkata-kata

Parasnya elok bagai di peta

Lemah lembut sandi anggota

Memberi belas di dalam cita

Abdul Muluk putera nin tuan

Besarlah sudah emas tempawan

Elok majelis tiada berlawan

Suka bermain cara pahlawan

Kutipan di atas menunjukkan salah satu bukti bahwa Raja Ali Haji selalu menjaga kehalusan budi dalam bertutur, dengan menyampaikan kata-kata pujian sehingga orang lain yang mendengarnya merasa tersanjung dan senang. Selain kehalusan budi pada tuturannya, yang membuat orang lain merasa tersanjung dan senang, melalui tuturan yang disampaikannya dapat ditangkap kualitas keimanan atau religiulitas yang dimiliki oleh Raja Ali Haji, dimana hal ini tercermin dari setiap kata-kata beliau yang bukan saja hanya pada Syair Abdul Muluk saja tetapi juga pada syair karya beliau lainnya.

Sebagai seorang intelektual muslim, hampir semua karya Raja Ali Haji mengandung nilai ketuhanan (religius), dengan demikian pada karya- karya beliau akan kita temukan amanat yang berkaitan dengan hubungan manusia sebagai makhluk dengan tuhan sebagai Sang Khalik. Hubungan itu menunjukkan kualitas kehalusan budi manusia kepada tuhan yang seyogianya dimiliki oleh setiap manusia sebagai ciptaan Allah. Setiap manusia wajib beriman kepada Allah sebagai Sang Pencipta segala Makhluk, tanpa kualitas keimanan itu berarti manusia mengingkari keberadaannya sebagai makhluk Allah. Hal ini merupakan pemikiran Raja Ali Haji yang dituangkan dalam Syair Abdul Muluk Bagian Tujuh Belas bait 56 yang berbunyi:

Barang apa pun melihat segala
Tuhan azzah wajallah
Jikalau sungguh asal kemala
Masakan cahaya tiada menyala

Sikap dan kepercayaan raja Ali Haji akan segala sesuatunya di dunia ini terjadi karena kehendak sang pencipta, dituangkan Raja Ali Haji lewat penceritaan Syair Abdul Muluk pada episode empat (koda). Pada bagian episode empat ini bait-bait syair mengangkat kisah tentang sifat sekaligus sikap tukang gandum, Si penolong Abdul Gani, putra Sultan Abdul Muluk dengan istrinya Siti Rafiah. Tukang gandum sangat yakin bahwa segala sesuatu yang terjadi di dunia ini karena kekuasaan Allah Subhanahuataallah.

Sifat dan sikap dari tukang gandum tersebut menunjukkan bahwa la beriman kepada Allah. Pesan kewajiban beriman kepada Sang Khalik itulah yang hendak ditonjolkan oleh penyair melalui bait-bait syairnya di atas. Kualitas kehalusan budi beriman kepada Allah yang dikisahkan diatas dimiliki oleh Si Tukang Gandum . keyakinan itu memang sedia adanya di dalam dirinya, penggambaran kualitas yang dimiliki oleh Tukang Gandum itu ditunjukkan oleh penyair karena kualitas itu 
memang telah ada dalam diri tukang gandum. Kualitas keberimanan kepada Allah yang ditunjukkan oleh Si Tukang gandum dalam karya ini juga digambarkan dengan mendeskripsikan perbuatan dan perkataan Si Tukang gandum, kesemuanya itu dapat dilihat, diamati dan didengar oleh orang lain. dengan demikian, potensi keimanan itu diwujudkan dalam perkataan dan perbuatan nyata. Artinya kualitas keimanan itu menurut Raja Ali Haji harus sejalan antara niat, perkataan, dan perbuatan. Tidak boleh terjadi lain yang diniatkan, lain pula yang dikatakan, lebih lagi yang dilakukan dalam perbuatan. Hal ini tidak hanya disampaikan Raja Ali Haji melalui Ayair Abdul Muluk saja, tetapi disetiap karya-karyanya beliau selalu mengutamakan dan menyampaikan kewajiban beriman kepada Allah.

Raja Ali Haji menggunakan pernyataan secara langsung, tanpa tokoh sebagai perantara, artinya kesemuanya itu disampaikan sesuai dengan nilai kebenaran yang diyakini oleh Raja Ali Haji. Dalam hubungan antara manusia dengan pencipta, karya Raja Ali Haji juga mengemukakan amanat agar manusia memula segala perbuatan yang baik dengan menyebut nama Allah. Hal ini terlihat pada Syair Abdul Muluk bagian I bait 1:

Bismillah itu permulaan kata

nama tuhan alam semesta

Akan tersebut Sultan Mahkota

Di negeri Barbari Baginda bertahta

Bait syair di atas Raja Ali Haji menceritakan bahwa beliau sendiri memulai syairnya dengan mengucapakan Bismillah yang bermakna 'dengan nama Allah'. Hal ini merupakan amanat yang tersirat walaupun tidak disebutkan dengan kalimat ' hendaklah segala manusia memulai sesutu dengan mengucap nama Allah'. Dalam kepemimpinan Raja Ali Haji adalah orang yang tidak mudah menyerah dan penuh tanggung jawab, beliau sudah dipercaya untuk melaksanakan tugas kenegaraan pada usia 20 tahun hingga 32 tahun. Dipercaya memerintah di daerah Lingga. Kepemimpinan yang diterapkannya tercermin pada Syair Abdul Muluk episode pertama (orientasi), bagian I bait $2-4$ :

Bismillah permulaan kata

Dengan nama tuhan alam semesta

Akan tersebut putera mahkota

Di negeri Barbari Baginda bertahta

Kata orang yang bijak bastari

Seorang Sultan negeri

Barbari gagah berani bujak bastari

Kabarnya masyur segenap negeri

Abdul Hamid Syah konon namanya

Terlalu besar kerajaannya

Beberapa negeri takluk kepadanya

Sekalian itu di bawah perintahnya

b. Hasil Interpretasi Makna Psikologis dalam Keluarga Penulis

Penafsiran makna teks secara psikologis dapat dilihat melalui latar belakang keluarga penulis yang lahir dan hidup dilingkungan budaya masyarakatnya. Lingkungan keluarga mempengaruhi setting dan plot penceritaan yang disampaikan oleh penulis.

Raja Ali haji adalah seorang sastrawan dan ulama besar dari Melayu. la adalah ulama, sejarawan, dan pujangga abad 19. Keturunan Bugis dan Melayu, la terkenal 
sebagai pencatat pertama dasar-dasar tata bahasa Melayu lewat buku Pedoman Bahasa. Beliau adalah putra Raja Ahmad, yang telah berhaji ke Mekkah. Raja Ali Haji menerima pendidikan dari lingkungan istana Kesultanan Riau-Lingga di Pulau Penyengat. Dia termasuk orang pertama yang dapat bersentuhan dengan pendidikan bidang agama, bahasa dan sastra, juga mendapatkan pendidikan dari luar lingkungan Kesultanan.

Melalui latar belakang kehidupan keluarga, masyarakat dan lingkungan Raha Ali Haji, maka dalam penulisan karya-karyanya terutama Syair Abdul Muluk banyak dipengaruhi oleh latar belakang kehidupan beliau, dimana pada Syair Abdul Muluk ini berlatar belakang keluarga kerajaan, kesultanan, bangsawan serta tata cara kehidupan keseharian mencerminkan kehidupan lingkungan kesultanan (istana sentris). Hal ini terlihat pada episode pertama sampai episode terkahir pada Syair Abdul Muluk.

c. Hasil Interpretasi Makna Psikologis dalam Generasi dan Masyarakat Penulis

Situasi dan keadaan generasi yang dialami oleh penulis juga mempengaruhi kualitas penulisan karyanya. Penulis akan lebih menonjolkan sesuatu yang menunjukkan identitas generasinya. Generasi masa yang dilalui penulis mau tidak mau dipengaruhi oleh masyarakat lingkungan penulis. untuk mendapatkan pemahaman penafsiran makna teks secara terang generasi, lingkungan, masyarakat penulis merupakan hal yang tidak dapat dipisahkan.

Pada masanya Syair Abdul Muluk ini cukup terkenal. Pertama kali Syair Abdul Muluk ini dimuat dan diterjemahkan dalam bahasa Belanda, pada masa masih berkuasanya kolonial Belanda (1847-1873), merupakan masa berkembangnya kesusastraan Islam dan melayu, atau penulisan sejarah masyarakat Melayu. Contoh perkembangan kesusastraan Islam ini terlihat dari banyaknya karya-karya yang dihasilkan Raja Ali Haji saat itu, baik berupa syair, kitab pengetahuan bahasa, maupun silsilah keluarga Raja-raja Melayu.

\section{d. Hasil Interpretasi Psikologi dalam Kultur atau Budaya Penulis}

Memahami teks secara psikologis terkait dengan kultur dan kebudayaan berdasrkan kondisi kebudayaan, dimana penulis hidup. Hasil karya yang dihasilkan oleh penulis tidak pernah meninggalkan ciri khas kultur dan budaya yang sudah melekat pada diri penulis. budaya /kultur masyarakat dalam teks karya sastra merupakan cerminan budaya yang ada ketika teks sastra tersebut diciptakan.

Teks Syair Abdul Muluk Karya Raja Ali Haji kultur budaya yang melatarbelakangi karyanya sangat kental ditonjolkan. Hal ini terlihat dari bait-bait syair yang kental dengan lingkungan masyarakat Melayu yang merupakan cerminan budaya yang ada ketika syair tersebut diciptakan. Beberapa hal yang dapat dilihat dari kutipan Syair Abdul Muluk ini yang sangat menonjolkan kebudayaan dan kultur melayu, terutama sekali penggunaan bahasa Melayu. Terdapat beberapa kosa kata 'Melayu Lama' , seperti kata kerdu-kerdam, tingkap, segah, cerpu, dan beberapa kata lainnya. Tiap-tiap Syair Abdul Muluk selalu menggunakan bahasa Melayu yang kental dan mempunyai ciri khas tersendiri seperti terlihat pada kutipan teks bagian tiga bait 22:

Sudah memamaki muda bangsawan

Wajahnya cemerlang kilau-kilauan

Cantik majelis barang kaluan

Patut yang muda dipertuan

Putera memakai selesailah sudah

Lalu dipimpin duli khalifah 
Di atas perarakan dinaikkanlah

Terkemabnglah payung ke puncak bertahta.

Ciri bahasa Melayu lama cenderung mengunakan kalimat yang berbelit-belit, tidak langsung kepada tujuan utama kalimat tersebut disampaikan, selalu menggunakan awalan-awalan yang merupakan sampiran dan baru menuju ke isi utama maksud dalam kalimat. Selain bahasa Melayu yang merupakan kultur dan budaya yang ditonjolkan, Raja Ali haji juga menonjolkan sifat dan prinsip perempuan Melayu melalui penonjolan penceritaan kekuatan wanita Melayu, yang memiliki kekuatan yang tidak kalah kuatnya dengan laki-laki. Seorang perempuan melayu harus setia dan mampu membela kesusahan suami, yang terlihat dalam Syair ini dimana Sitti Rafiah yang berhasil melepaskan suaminya Sultan Abdul Muluk yang ditawan oleh Raja Hindustan, Setelah melalui berbagai macam rintangan. Kehebatan dan kekuatan perempuan yang ditonjolkan oleh Raja Ali Haji, merupakan penggambaran ciri dan kebudayaan serta kebiasaan perempuan Melayu yang tidak tinggal diam dan hanya berserah diri kepada keputusan takdir. Kekuatan perempuan Melayu pada Syair Abdul Muluk terlihat pada syair bagian sembilan bait ke 41- 44:

Rafiah pun sangat rasa ngeri

Menghunus pedangnya bangkit berdiri

Binatang menerkam datang berlari

Diturunkan pedang oleh putri

Setelah mati sudahlah binatang

Kepada misainya la terpandang

Hanya lah sehelai terlalu panjang

Panjangnya konon sebelit pinggang

Misai binatang sudah diambilnya
Lalu diikatkana kepada pinggangnya
Hilanglah segala letih lesunya
Jadilah kuat perasaannya

Kultur dan budaya kehidupan perempuan Melayu tidak hanya diangkat Raja Ali Haji ke dalam Syair Abdul Muluk saja, tetapi disetiap karya-karya lainnya beliau selalu menepatkan posisi perempuan melayu pada kedudukannya yang layak berdasarkan harkat dan martabatnya.

Kultur budaya lainnya yang diangkat oleh Raja Ali Haji dalm Syair Abdul Muluk adalah unsur kebudayaan, dimana pada teks Syair Abdul Muluk ini, kebudayaan bangsa Melayu yang harus dipatuhi dalam sistem perdagangan, dimana ada keharusan bagi semua pedagang untuk melaksanakan atutran-aturan dagang yang berlaku di masyarakat Melayu. Hal ini diceritakan Raja Ali Haji dalam teks Syair Abdul Muluk, dimana semua pedagang harus melaksanakan aturan dagang yang berlaku di negeri Barbari.

\section{e. Hasil Interpretasi Makna Psikologis Negara dan Zaman Penulis}

Situasi wilayah dan sistem pemerintahan, serta zaman, mempengaruhi setiap karya-karya yang diciptakan oleh penulis. dimana sistem pemerintahan dan zaman akan ditonjolkan oleh penulis melalui penceritaan. Secara konsep ide kepengarangan dalam penyampaian penceritaan terutama syair akan dipengaruhi oleh sisten negara / pemerintahan pada masa berkembangnya syair tersebut diciptakan, sesuai dengan konvensi zaman yang menjadi dasar dalam penceritaan. 
Syair Abdul Muluk bedasarkan telaah teks situasi, kondisi, pemerintahan dan zaman keika karya ini diciptakan oleh Raja Ali Haji berlatarkan sistem perintahan kerajaan / kesultanan Melayu yang dipimpin oleh seorang Sultan dan berlatar suasana istana sentris.

Raja Ali Haji banyak menghasilkan karya dan tidak pernah meninggalkan ciri khasnya, yaitu akar tradisi kesustraan Isalam dan melayu disajikan dalam sejarah masa lalu disesuaikan dengan tuntutan kondisi dizamannya. Penceritaaan keluarga kerajaan yang berlandaskan tradisi keislaman mempengaruhi sistem pemerintahan kesultanan Barbari, dimana hal ini sesuai dengan pengalaman pribadi secara individu seorang Raja Ali haji yang dibesarkan di lingkungan keluarga kerajaan, hidup di lingkungan istana kesultanan, dan bahkan beliau sendiri pun pernah memimpin suatu wolayah pada masanya.

Sistem pemerintahan kesultanan dan istana sentris dapat dilihat pada teks Syair Abdul Muluk bagian I bait $3-4$ :

Kata orang yang bijak bastari

Seorang Sultan Negeri Barbari

Gagah berani bijak bastari

Kabarnya masyur segenap negeri

Abdul Hamid Syah konon namamya

Terlalu besar kerajaannya

Beberapa negeri tunduk padanya

Sekalian di bawah perintahnya

Teks bagian 3 bait $13-15$;

Sudah bertitah raja yang gana

Berangkat masuk ke dalam istana

Akan masyur yang bijaksana

Mengajukan titah yang sempurna

Telah datang keesokan hari

Berhimpun sekalian seisi negeri

Serta dengan anak istri

Mansyur menghiasi balairung seri

Orang mengalur sudahlah selesai

Dari istana sampai ke balai

Indah rupanya tiada ternilai

Segala yang melihat heran dan lalai

\section{PEMBAHASAN}

Pembahasan hasil penelitian telaah makna Syair Abdul Muluk berdasarkan pendekatan Hermeneutika Schleirmacher menunjukkan bahwa Syair Abdul Muluk termasuk ke dalam karya fiksi dari hasil olahan penulis berdasarkan pandangan, tafsiran, dan penilaian tentang peristiwa-peristiwa yang pernah terjadi yang berlangsung dalam khayalan sebagai presentasi dari budaya raja yang bijak. Hal ini sesuai dengan pendapat Zaini-Lajoubert (1994:23) bahwa Syair Abdul Muluk karya Ali Haji merupakan syair yang dihadirkan sebagai cerminan budaya kehidupan raja yang santun dan bijak terhadap setiap orang. Syair Abdul Mulu juga bermakna 
hendaklah kita menjadi orang santun, bijak, dan baik budi agar dihormati dan dicintai sesama.

Dalam studi sastra teori Hermeneutika bekerja pada pemahaman dalam menafsirkan teks, dimana pemahaman tersebut difokuskan pada peristiwa pemahaman teks dan persoalan yang lebih mengarah mengenai pemahaman dan interpretasi (Ratna, 2013: 230). Hal ini memperlihatkan bahwa gagasan utama dalam Hermeneutika adalah pemahaman pada teks. Pada setiap pendekatan apresiasi karya sastra banyak penelitian yang menggunakan pendekatan Hermeneutika, pendekatan ini berfokus pada proses penangkapan makna dalam bahasa yang menghubungkan antara bagian-bagian teks dengan keseluruhan teks.

Pendekatan Hermeneutika dalam kajian karya sastra menghubungkan interpretasi gramatis secara keseluruhan dengan interpretasi psikologis yang saling mengandalkan, merupakan satu kesatuan yang tidak dapat dipisahkan. Interpretasi secara gramatis analisis makna berfokus pada tuturan-turan bahasa yang digunakan oleh penulis pada karyanyayang berupa kata, kalimat, alinia, bagian-bagian teks, keseluruhan teks, dan genre pada teks. Begitu juga dengan dengan interpretasi psikologis yang menganalisis berdasarkan individu penulis, keluarga, generasi, kultur budaya, serta zaman yang dialami oleh penulis. interpretasi psikologi tidak bisa tidak harus diikuti oleh interpretasi secara gramatis, karena untuk menentukan makna secara psikologi penulis, hanya dapat dipahami melalui teks yang ditulis oleh penulis, melalui tuturan bahasa yang disampaikan penulis.

Syair Abdul Muluk karya Raja Ali Haji yang merupakan karya fiksi, yang disebut juga sebagai cerita rekaan, ialah cerita dalam olahan pengarang berdasarkan pandangan, tafsiran dan penilaiannya tentang peristiwa yang pernah terjadi, ataupun pengolahan tentang peristiwa yang berlangsung dalam khayalan. Akan tetapi, walaupun dalam bentuk khayalan tentang apa pun bentuk penceritaannya, bisa dipastikan ide yang mengalir dalam kepengarangan itu pernah terjadi dan terlintas dalam kepengarangan itu sendiri, terutama dalam penceritaan Syair Abdul Muluk yang sangat kental dengan latar istana sentris.

Interpretasi makna gramatis pada telaah Syair Abdul Muluk yang terdiri dari interpretasi makna kata, kalimat, alinia, bagian teks, keseluruhan teks, dan genre teks cakupan analisisnya bergerak pada pemaknaan simbol dan tanda melalui sisten ketandaan atau semiotika. Pada kajian gramatikal ini, tidak dapat dipungkiri jika kita melakukan telaah makna secara gramatikal mau tidak mau, semiotika sedikit banyak akan mendukung hasil pemaknaan.

Kajian Syair Abdul Muluk karya Raja Ali Haji banyak ditemukan berbagai bentuk tanda yang terdiri dari simbol, icon, dan indeks. Tanda-tanda ini tersebar dalam semua bagian dan episode yang ada pada syair. Tanda-tanda ini terlihat pada setiap kebahasaan yang memiliki makna tersirat, melalui tuturan-tuturan yang dilontarkan antar tokoh.

Berdasarkan cara kerja Hermeneutika, dalan Syair Abdul Muluk penanda dapat dilihat pada latar cerita yang diceritakan dalam syair ini. Icon, simbol, dan indeks muncul dalam kebahasaan yang bersifat pararel, dimana pada analisis gramatikal interpretasi makna kata tidak dapat hanya dianalisis pada kata saja, tetapi juga harus mengikut sertakan kajian makna kalimat yang bukan merupakan gabungan kata tetapi juga kajian interpretasi alinia yang merupakan akumulasi dari kata dan kalimat. Jika menganalisis alinia maka mau tidak mau bagian-bagian teks juga akan mengiringi secara tidak langsung kegiatan pemaknaan. Selanjutnya secara keseluruhan teks, makna icon, simbol, dan indeks akan lebih jelas dalam 
pemahaman teks, dan akan lebih memudahkan peneliti untuk melakukan kegiatan penafsiran dan telaah makna terhadap teks syair.

Sistem ketandaan pada Syair Abdul Muluk dapat dilihat pada setting cerita yang terdapat pada episode pertama yang merupakan orientasi, penyampaian cerita tentang empat kerajaan besar dan masalah-masalah manusia yang ada di dalamnya. Sistem ketandaaan faktual dimainkan oleh tokoh-tokoh dalam Syair Abdul Muluk pada peran mereka dalam pemaknaan teks. Tokoh Abdul Muluk berkedudukan sebagai icon yang berfungsi sebagai penghubung sebab-akibat yang akan menimbulkan simbol, dalam hal ini penerus kerajaan.

Penafsiran makna secara gramatis pada Syair Abdul Muluk dilakukan pada bagian-bagian teks, dimana pada Syair Abdul Muluk ini merupakan syair yang cukup panjang maka dibagilah syair tersebut ke dalam empat epidose dari 18 bagian baitbait syair. Hal ini sesuai dengan pendapat Fang (1993:201) bahwa syair sebagai jenis puisi lama lebih panjang dibandingkan dengan jenis puisi lainnya yang terdiri dari empat baris; setiap baris mengandung empat kata yang sekurang-kurangnya terdiri dari sembilan sampai dua belas suku kata. Pembagian ini berdasarkan struktur penceritaan dilakukan berdasarkan interpretasi terhadap kata, kalimat dan alinia yang terdapat pada teks syair tersebut. Secara keseluruhan teks pengelompokan bagian-bagian teks ke dalam episode-episode berdasarkan struktur penceritaannya, menghasilkan makna dari teks Syair Abdul Muluk, yang disampaikan penulis bahwa perempuan Melayu memiliki kekuatan yang tidak kalah dengan laki-laki, kesetiaan seorang perempuan melayu terhadap suami dan keluarganya, yang merupakan ciri dan prinsip hidup perempuan Melayu yang tidak mudah menyerah terhadap situasi serta keadaan. secara genre Syair Abdul Muluk termasuk ke dalam bentuk puisi lama, karena terikat oleh bentuk dan rima.

Berdasarkan analisis gramatikal maka dapat ditangkap maksud, pesan, dan amanat yang akan disampaikan oleh Raja Ali Haji. Kesemuanya itu dapat diketahui melalui tuturan-tuturan yang disampaikan oleh Raja Ali Haji dalam kebahasaan yang digunakan Raja Ali Haji dalam teks. Raja Ali Haji menempatkan karya ke dalam konteks sosial, dimana kepribadian, pikiran-pikiran Raha Ali Haji dapat dipahami melalui bahasa yang disampaikan. Melalui tuturan bahasa tercermin kehalusan budi dalam bertutur, kualitas keimanan, serta sifat tanggung jawab yang dimiliki oleh seorang Raja Ali Haji. Kemudian, pola umum yang terdapat dalam Syair Abdul Muluk karya Ali Haji sudah sesusi dengan pendapat Pradopo (1998: 26), yaitu memiliki ciri-ciri formal syair: a) satu bait terdiri dari empat baris (larik); b) tiap larik terdiri dari dua bagian yang sama; c) pola sajak (rima) akhir syair berupa sajak sama: a-a-a-a; d) keempat baris syair saling berhubungan membentuk cerita; dan e) syair bersifat epis, yaitu berupa cerita.

Dari segi kepribadian individu, serta pikiran-pikiran Raja Ali Haji sehingga secara psikologis bahwa Raja Ali Haji adalah seorang yang berbudi, halus budi bahasa, religius, dan tanggung jawab adalah hasil dari latar belakang keluarga beliau yang hidup dikeluarga lingkungan kerajaan yang berpendidikan tinggi. Penceritaan pikiran-pikiran Raja Ali Haji juga dipengaruhi oleh masyarakat dan generasi, dan zaman yang dilalui oleh Raja Ali Haji. Hal ini mempengaruhi karya-karya yang diciptakan beliau berdsarkan perkembangan kesusastraan pada saa, dimana pada masa itu sedang berkembangnya kesusastraan Islam, sehingga karya-karya Raja Ali Haji selalu bernuansa Islam dan melayu.

Berdasarkan kondisi kultur dan budaya kehidupan Raja Ali Haji, karya yang dihasilkan oleh beliau tidak pernah meninggalkan ciri khas kultur dan budaya yang 
selalu melekat pada dirinya. Teks Syair Abdul Muluk ini menonjolkan kultur budaya masyarakat Melayu lama, terutama dalam penggunaan bahasa Melayu. Terdapat beberapa kata Melayu Lama yang tidak pernah lagi digunakan oleh masyarakat Melayu pada saat ini. Selain kata lama, bahasa Melayu yang dituturkan oleh Raja Ali Haji, kalimatnya cenderung berbelit-belit tidak langsung kepada tujuan utama kalimat yang ingin disampaikan, hal ini merupakan ciri utama dari bahasa Melayu lama.

Penceritaan Syair Abdul Muluk dipengaruhi oleh zaman dan situasi sistem pemerintahan yang pernah dilalui Raja Ali Haji ketika Syair Abdul Muluk diciptakan. Zaman kerajaan dan istana sentris yang pernah dilalui oleh Raja Ali Haji mempengaruhi penceritaannya, ini terlihat dari latar tempat yang disajikan dalam Syair Abdul Muluk. Ali Haji sangat piawai dalam mengemas bahasa menjadi sebuah syair dengan tujuan memberikan hidup tentang pentingnya sikap bijaksana terhadap sesama dalam hal ini raja terhadap keluarga, bawahan, dan rakyatnya. Bahasa yang digunakan dalam syair begitu indah dan mengandung nilai moral sehingga penting diajarkan kepada siswa. Hal ini dikarenakan karya sastra dan pengajaran bahasa memang saling melengkapi, terutama dalam pembelajaran bahasa, guru selalu menggunakan karya sastra sebagai objek utamanya dalam menjelaskan ciri dan fungsi suatu bahasa (Noermanzah, 2017:28).

\section{KESIMPULAN DAN SARAN}

Berdasarakan hasil penelitian dan pembahasan dapat disimpulkan bahwa makna Syair Abdul Muluk karya Raja Ali Haji dengan menggunakan pendekatan Hermeneutika Schleirmacher yaitu:

1. Secara gramatikal Syair Abdul Muluk karya Raha Ali Haji, mengandung Icon, simbol, dan indeks berdasarkan interpretasi makna kata dan kalimat yang terdapat pada semua teks Syair Abdul Muluk. Dalam kajian makna syair ini. Interpretasi alinia dan bagian-bagian teks dimana teks Syair Abdul Muluk terdiri dari 18 bagian, memiliki empat episode yang terdiri dari, episode pertama (orientasi), episode kedua (komplikasi dan evaluasi), episode ketiga (resolusi), dan episode keempat ( koda). Pembagian episode ini berdasarkan struktur penceritaan pada bait-bait syair yang ada pada teks, sehinggga secara keseluruhan teks, dapat ditangkap makna Syair Abdul Muluk yaitu syair yang berbentuk fiksi yang bertemakan tentang kegigihan dan kekuatan seorang perempuan Melayu dalam bertahan hidup untuk tetap setia kepada suami dan berusaha melepaskan keluarganya dalam kesulitan dan kesengsaraan.

2. Untuk mendapatkan pemaknaan dan penafsiran secara psikologis, dimana pemaknaan ini dilakukan melalui interpretasi individu, keluarga, kultur budaya, masyarakat, generasi, dan zaman dari Raja Ali Haji. Dapat diketahui melalui telaah makna tuturan antar tokoh yang disampaikan Raja Ali Haji melalui penceritaan pada Syair Abdul Muluk. Makna psikologi yang terdapat pada Syair Abdul Muluk, berdasarkan individu penulis menunjukkan bahwa Raja Ali Haji adalah seorang sastrawan dan ulama besar yang memiliki kehalusan budi bahasa, memiliki kualitas religius yang tinggi, serta memiliki rasa tanggung jawab tanggung jawab yang besar sebagai seorang pemimpin. Hal ini berdasarkan latar belakang keluarga Raja Ali Haji yang hidup di kalangan istana, dan latar belakang keluarga kerajaan yang memiliki pendidikan tinggi pada masa itu. Karya yang diciptakan oleh Raja Ali Haji sangat dipengaruhi oleh masyarakat, generasi, serta kultur budaya pada saat karya itu diciptakan. Dimana Syair Abdul Muluk yang kental 
dengan kebudayaan masyarakat Melayu, terutama Melayu lama, yang terlihat pada penggunaan bahasa yang digunakan Raja Ali Haji, kebiasaan dan pola hidup serta latar belakang istana sentris juga ditonjolkan oleh Raja Ali Haji dalam penciptaan Syair Abdul Muluk ini.

Dari hasil penelitian ini, diharapkan bahwa Syair Abdul Muluk karya Raja Ali Haji dapat dijadikan salah satu bahan ajar yang dapat digunakan dalam pembelajaran syair baik pada tingkat sekolah dasar maupun perguruan tinggi. Penekanan karakter santun berbahasa, religius, dan bertanggung jawab bisa disampaikan kepada siswa pada naskah Syair Abdul Muluk.

\section{DAFTAR PUSTAKA}

Arfani, M. (2016). Inilah Syair Abdul Muluk : tentang Struktur dan Teks Karya Raja Ali Haji. Palembang: Komunitas Titik Awal.

Braginsky. (1998). Tasawuf dan Sastra Melayu, Kajian dan Teks. Jakarta: RUL.

Djajasudarma, F. (2013). Semantik 2. Bandung: PT Relika Aditama.

Fang, L. Y. (1993). Sejarah Kesusastraan Melayu Klasik. Jakarta: Erlangga.

Noermanzah, N. N. (2017). Plot in a Collection of Short Stories "Sakinah Bersamamu" Works of Asma Nadia with Feminimism Analysis. Humanus, 16(1), 27. doi:10.24036/jh.v16i1.7015

Pateda, M. (2010). Semantik Leksikal. Jakarta: PT Rineka Cipta.

Pradopo, R. D. (2012). Pengkajian Puisi. Yogyakarta: Gadjah Mada University Press.

Ratna, N. K. (2013). Stilistika Kajian Puitika Bahasa, Sastra, dan Budaya. Yogyakarta: Pustaka Pelajar.

Rudianto. (2013). Analisis Nilai-Nilai Budi Pekerti dalam Syair Abdul Muluk Karya Raja Ali Haji. Tesis, Universitas Maritim Raja Ali Haji. http://jurnal.umrah.ac.id/?p=423

Zaini-Lajoubert, M. (1994). Le syair cerita Siti Akbari de Lie Kim Hok (1884) ou un avatar du Syair Abdul Muluk (1846). Archipel, 48(1), 103-124. doi:10.3406/arch.1994.3005 